\title{
Study on the Development of Education: Contextual Secondary Education in Papua
}

\author{
Hans Hamadi \\ Cenderawasih University, Indonesia \\ westim_ratang@yahoo.co.id
}

\begin{abstract}
Utilizing knowledge of education to manage technology as modern human lifestyles and meet the demands of work and life is the subject of this study. While those living in the suburbs to meet the demands of education, utilizing information technology as a way of life will come to their rescue. They also still use the natural wealth of forests, mountains and oceans as a source of learning and life. In remote areas, technology and the demands of rapid change, are sluggish and does not make the technology as a necessity of life. They depend on nature to meet their educational knowledge as well as the necessities of life. How technology can be implemented and enjoyed on this earth without distinguishing its diversity. They utilize contextual nature as education and then institutionalized it in teaching. Every human being has the same rights and if in fact there is a gap it means that there is injustice. So there are things that need to be repaired. The knowledge and skills of human resources in the context of this study are defined as an entity of teachers. Human and organizational resources, which indeed underlies the base of organizational performance. There is a substantive difference between knowledge and skill. The concept of knowledge is more oriented to intelligence, intellect, and extensive mastery of knowledge and the narrowness of insight that one. This is a qualitative descriptive study based on the paradigm of post positivism. Qualitative research is still using the theories and concepts that are not tested as in positivism paradigm. The results of the study of literature are (1) The need for establishing educational institutions in each region are categorized as remote and isolated areas. (2) Closer direct services to remote and isolated areas then form the institution can be either natural school. (3) Adequate education that is modified and performed should remain principled and lead to economic value, efficiently utilize the environment without leaving the quality of education. Efforts to render these services is in line with Government Regulation No. 19 Year 2005 on National Education Standards, at the school level, which can be used as a referral to the rule above are: (1) education as a process of acculturation and empowerment. (2) Education in order to increase the nation's competitiveness. (3) Education for development. (4) Education for affirmative action / serving disadvantaged communities. (5) The commitment to the policy of providing certain types of education.
\end{abstract}

Keywords: Education, contextual, strategy, service

\section{Introduction}

Education creates life changing opportunity, breaks the chain of poverty and ignorance and disease, provides a foundation for sustainable development. Quality education to equip children with the knowledge and skills needed to adopt the lifestyle, to protection, play an active role in every activity. This became the lofty ideals of education itself, including education in Papua. Papua who a new civilization since 5 February 1855, has transformed itself as what was quoted and written by Rainer "I have written all this in love and in their openness. With joy I can say that Dawn has been split in Papua "(Rainer, 2004: 11). Education in Papua continues to develop forward since the entry of a new civilization. Dawn has been split in Papua is a beacon in the work in Papua, but in general cannot be equated with other regions in Indonesia. Papua is region which culture share position in indigenous areas that affect cultural diversity education into seven great cultures.

Progress is marked by the presence of the new culture and the "force" of local culture to immediately eroded, it begins with the arrival education took place in three learning environment, namely education units, families and communities. The education process at every learning environment in which ongoing process of cultural transformation, the process of personality formation, the development of knowledge and skills training Today the Indonesian government through educational and cultural ministry attempts to achieve educational equity. Efforts ministry for educational equity go hand in hand with efforts to improve the quality, relevance and competitiveness. It is the government doing to increase and improvement of human resources, have sufficient knowledge and strong character, cultured and civilized. To achieve a quality of education that is able to compete nationally and globally, the institutional structure of education in Papua in 
order to adjust the conditions geographical and socio-cultural conditions of the Papuan people scattered in the city, suburban and remote (Felix Minggus Degei, 2014).

The same problems are also experienced in improving the quality of secondary education. Facts show that the quality of secondary education in various counties and cities in Indonesia is still worrying, for example, the lack of competitiveness of alumni and distribution of their work. Another with regard to the phenomenon has not quality education that occurred previously. For example, in the province of Papua, that the secondary education program that is not synergistic with the local cultural context, the readiness of resources and opportunities existing policies, so it is still difficult implementation of education based on community or contextual component-oriented education rather than mere knowledge. Contextual Education itself is a learning process approach that prioritizes aspects of the context and the role of environment in shaping the thought pattern and learners. This view is supported by the analysis of Johnson (2002) which states that constructivism (constructivism) is the foundation of thought (philosophy) contextual learning.

\section{Literature Review}

Education Theory: According, Sukmadinata (2009) in his book Widiastono (2009) there are four educational theories underlying institutional models, namely the classical education, private education, education and education technology interactional. The development of the theory contained therein curriculum, teachers, students, and other supporting facilities in promoting and running the institutions.

- Classical Education: The concept of classical education (classical education) proceed from the assumption that the entire cultural heritage, covering knowledge, ideas, or values have been found by experts earlier. "Education serves to maintain, preserve and pass on the cultural heritage to the next generation.

- Private Education: The concept of private education (personalized education) proceed from the assumption that since at birth, the child has been equipped with the grace of God as the potential to think, do, solve problems, learn, and grow their own. "Education is like a nursery function creates a supportive environment and protected from pests and diseases."

- Education technology: In educational technology is more oriented to the present and future needs, different from the Mecca of classical education in the past. According Rickey (2008) were written back in his Widiastono "educational technology is the study and practice to help the learning process and improve performance by creating, using, and managing processes and resources adequate technology"

- Interactional education: This educational concept from the assumption that humans as social beings in life always need another human being. Humans are essentially social beings, and in its development, he needs someone else. Since human beings are born it requires association with others to meet their needs. The need for the purposes and activities of day-to-day depend on others.

- Theory Reconstruction: Reconstructive see the existence of society can benefit by performing tasks according to the development over time. The state of society at large to see and experience the change of life farther and advanced from being in the natural as well as in live it. The development of science, technology, and industrialization has contributed positively to humanity, such as increased welfare, but on the other hand is also a member of negative impacts.

Contextual Education: Contextual approach is the brain's system (forming) a pattern to express meaning. CTL is a teaching system that matches the brain that produce linking academic content to the context of students' everyday lives. Contextual approach to learning is a concept on the philosophy of constructivism. According to the philosophy of constructivism, temporary and always changing. Everything is temporary, changing and uncertain. We are the ones who give meaning to reality (Trianto, 2008).

\section{Decentralization Implementation of the Education Sector}

- The concept of decentralization: Definition of decentralization differentiated into two of terminology. First, decentralization meaningful as "Devolution" which shows his understanding of 
political authority sense legally and selected locally. Second, the notion of decentralization in the concept of "deconstructive" which refers to the understanding of the administrative authority (administrative authority) given to the representatives of central government agencies and local a country.

- Implementation of Government Affairs Education: The amount of authority given to the government of local / regional in a relatively short time is a strength of the region is remarkable for its existence and build self-reliance with which boundaries clear. Therefore then, according to Henry (1995: 79) the authority and supervision of the lots owned by the investigator, and thus the investigator must truly professional and independent in performing its duties and functions. If it is compared with Indonesia seems very different, which is based on regional autonomy laws submitted to the central government in the form of local government authorities, regional approaches and budgets to be managed optimally with the involvement and empowerment. These conditions are expected that service to the community closer and know the shortcomings that exist in the community, the local government as an autonomous regional authorities know exactly what is needed by the people in the acceleration of development.

\section{Methodology}

Types of research: This is a qualitative descriptive based on the paradigm of post positivism, that qualitative research is still using the theories and concepts that are not tested as in positivism paradigm. This study uses a case study approach, which explores a process of observation of the implementation process of institutional improvement in the process of contextual education in the province of Papua. Cases observed are covering various related to the institutional development process of contextual the education, it can support and hinder institutional elements and readiness in anticipation of contextual education problems in Papua.

Sources and Data Analysis Techniques: Source of research data are derived from two main data sources, namely primary data and secondary data analysis is qualitative descriptive analysis techniques, with reference to the previous literature.

\section{Results}

Contextual Approach or Contextual Teaching and Learning (CTL): Contextual Approach or Contextual Teaching and Learning (CTL) are very significant responses on a situation like this in the world are literally. Definition This learning approach is the concept of learning that help teachers link between what is taught with real world situations students and encourage students make the connection between knowledge possessed by the application in their lives as members of the family and society. The underlying philosophy in Implementation Contextual Approach or Contextual Teaching Learning (CTL) is learning based on what is around the students. So the main focus in this learning method is that the students, instead of focusing on a teacher (teacher centered) .a teacher only acts as a facilitator and mediator in learning. So it is understood that in the application of this approach it is possible for the occurrence of some forms of indirect learning experienced by students. Ideally a minimum of five forms of learning that occurs in the teaching and learning activities (KBM), among others:

a. Associating (Relating): Hooking is the most powerful strategy and is the core of constructivism. A teacher uses this strategy linking the new concept with something that is already known to the students. So thus, linking what students already known the information context in Papua, every teacher who educates he should be able and willing to associate a new concept in theory with what things are there in the Nature Papua. The hope is that the students can be active and creative in understanding without having to fantasize something that is not really on their minds.

b. Experiencing (Experiencing): Experiencing the core contextual learning where hooking means connecting new information with experience equipment and materials as well as carry out research that forms, that after the students associate with whatever is around they are, so it is sure they will experience in understanding the application of a particular theory. In the context of Papua, that the examples given in the material should be about the things that most cannot be experienced by the 
students because there are around with students experiencing something will certainly be more difficult to forget, rather than just studying theory alone,

c. Apply (Applying): In this study students apply the concept when they teach with problem-solving activities. A master of duties only motivate students to practice realistic give and context in Papua understood that teachers who teach only in charge of giving impetus to the practices concerned with the real and whatever, that is also in Papua. It is considered very important because it deals with the relevance of the possibility of employment for men / I Papuan after completion of studies.

d. Cooperating (Cooperating): In this course students learn to form their own groups that will solve a problem thanks to the cooperation of a group of the students themselves. Because in this case the teacher only as a motivator and facilitator in the learning process of students. In the context of Papua, the experience of this cooperation will not only help students learn the material so that the students could also consistent with the real world of nature around students.

e. Transferring (Transferring): In a contextual approach one of the things will automatically happen to students is that they are directly understand because the object in question is around with other approaches is their students are only required to be able to understand how by rote. Thus, in the context of Papua understood that when a teacher gives examples should be in accordance with what is in Papua, then of course it will happen in students is to understand not just memorize.

In addition, according to the Ministry of National Education for its application, contextual approach (CTL) has seven major components, namely:

a. Constructivism (Constructivism): Constructivism is a cornerstone think CTL which emphasizes that learning is not just memorize, recall of knowledge but it is a learning process in which students themselves mentally active build knowledge based on the structure of its.

b. Finding (Inquiry): Finding the core of what this part of contextual based learning and skills acquired students are expected not result given set of facts, but the result of finding find (inquiry) is a cycle of observation (observation), ask (questioning), filed allegations, data collecting, inference (conclusion).

c. Ask (Questioning): The knowledge that one has always started from the main strategy contextually based. Activity ask useful to: 1) gather information, 2) explore the understanding of students, 3) generate a response to the student, 4) determine the extent to which the curiosity of students, 5) know the things that are already known to the students, 6) focuses attention on something desired teachers, 7) raised more questions from the students, 8) to refresh students' knowledge.

d. Learning Community (Learning Community): The concept of learning communities learning outcomes obtained from the cooperation of others. The results obtained from the study 'sharing' between friends, between groups, and between the know who have learning occurs when there are two-way communication, two or more groups involved in learning communication learn from each other.

e. Modeling (Modeling): Modeling basically paraphrases think, demonstrate how teachers want their students to learn and do what teachers want the students do. Contextual learning, the teacher not only design to engage students and also bring in from outside.

f. Reflection (Reflection): Reflection is a way of thinking or a response about what had learned or backward to think about what has been done in the past. Realization in learning, teachers leaving a moment that the students reflect on the form of a direct statement of what you earned that day.

g. The actual assessment (Authentic Assessment): Assessment is the process of collecting a variety of data that can give an overview on the development of students' learning. In the CTL based learning, on the development of students' teachers need to know in order to ensure that students have a true learning. The focus is on the completion of assessment tasks that are relevant and contextual and assessment is carried out on the process and results.

\section{Business Strategy Providing adequate services are:}

- The need for establishing educational institutions in each region has categorized as remote and isolated areas.

- Closer direct services to remote and isolated areas then form the institution can be either natural school

- Adequate education that is modified and performed should remain principled and lead to economic value, efficiently utilize the environment without leaving the quality of education. 
Efforts to render these services is in line with Government Regulation No. 19 Year 2005 on National Education Standards, at the school level, which can be used as a referral to the rule above is:

- Education as a process of acculturation and empowerment.

- Education in order to increase the nation's competitiveness.

- Education for development.

- Education for affirmative action / serving disadvantaged communities.

- The commitment to the policy of providing certain types of education.

\section{Conclusion}

Contextual Approach or Contextual Teaching and Learning (CTL) is a very significant response on a situation like this in the world are literally and definition This learning approach is the concept of learning that help teachers link between what is taught with real-world situations students and encourage students make the connection between knowledge possessed by the application in their lives as family members and (CTL) has seven major components, namely: Constructivism, Finding, inquiry, Community Learning, modeling, Reflection, the actual assessment. Business Strategy Service Delivery adequate is: (1) the need for establishing educational institutions in each region are categorized as remote and isolated areas. (2) Closer direct services to remote and isolated areas then form the institution can be either natural school. (3) Adequate education that is modified and performed should remain principled and lead to economic value, efficiently utilize the environment without leaving the quality of education.

\section{References}

Felix Minggus Degei. (2014). Was Assistant Lecturer Study Program Guidance and Counseling (Psychology) FKIP Cenderawasih University in Jayapura, Papua. Tabloidjubi.com> Letters \& Donations Readers

Johnson, E. B. (2002). Contextual Teaching and Learning. California: Corwin Press, Inc.

Rainer, S. (2004). Dawn in Papua Papua Apostles Life and Work: Johann Gottlob Geissler (1830-1870) and legacy Present. Jayapura: 150 Gold's Committee Jubelium Evangelism Day in the Land of Papua.

Sukmadinata, N. S. (2009). Metode Penelitian Pendidikan . Bandung: PT Remaja Rosdakarya.

Widyastono, H. (2009). Mengembangkan Kreativitas Peserta Didik dalam Pembelajaran. Jurnal.

Henry, S. (1995). Manajemen Sumber Daya Manusia.Yogyakarta: Bagian Penerbitan STIE YKPN.

Trianto. (2008). Mendesain Pembelajaran Kontekstual Di Kelas. Jakarta: Cerdas Pustaka Publisher. 